Int. J Veuropharmacol., 1963, 2, 51-55. Pergamon Press. Printed in Gt. Britain. [4 figs., 10 refs.]

\title{
SPECIES DIFFERENCES IN THE EEG RESPONSE TO EPINEPHRINE, 5-HYDROXYTRYPTAMINE AND NICOTINE IN BRAINSTEM TRANSECTED ANIMALS, ${ }^{*}+$
}

\author{
DONALD E. KNAPP + and EdwaRd F. DOMINo \\ Department of Pharmacology, The University of Michigan, Ann Arbor, Michigan
}

\begin{abstract}
Summary-Species differences have been observed in the EEG activation response to intravenous epinephrine, 5-hydroxytryptamine, and nicotine in rabbits, cats, dogs and monkeys. It was also found that a relatively high level of brainstem transection was required to induce a slow wave EEG pattern in the monkey. In midpontine** rabbits, cats and dogs and high pontine monkeys EEG activation was seen after $10-20 \mu \mathrm{g} / \mathrm{kg}$ of nicotine. Similar doses of nicotine also produced EEG activation in prepontine rabbits and cats but not in the prepontine dog. Also, whereas $4-8 \mu \mathrm{g} / \mathrm{kg}$ of epinephrine and $30 \mu \mathrm{g} / \mathrm{kg}$ 5-hydroxytryptamine produced EEG activation in the midpontine rabbit and cat, no such response was observed following the administration of these agents in the midpontine dog or high pontine monkey.
\end{abstract}

\section{INTRODUCTION}

ABL $D$ DANT literature exists regarding the electroencephalographic (EEG) effects of epinephrine and related drugs LONGO (1962) has summarized his own observations and reviewed the literature. It is interesting that the rabbit and the cat have been studied most extensively. Surprisinlgy little data are available on the EEG effects of epinephrine and related drugs in other species. It is sometimes assumed that results obtained using rabbits and cats are directly applicable to man, especially inasmuch as intact humans show similar EEG changes in response to the injection of epinephrine (GibBs and Maltby, 1943). Nevertheless, species differences may be important (KNAPP and Domino, 1961) KNAPP and Domino (1962) have shown that the intravenous injection of neither epinephrine $(8 \mu \mathrm{g} / \mathrm{kg})$ nor 5 -hydroxytryptamine $(30 \mu \mathrm{g} / \mathrm{kg})$ produced EEG activation in midpontine dogs although the administration of $10-20 \mu \mathrm{g} / \mathrm{kg}$ of nicotine was routinely effective. In order to rule out the technique of transection as the reason for these unexpected results and to explore some possible species differences, similar experiments were performed on rabbits, cats and monkeys.

\section{METHODS}

A total of 28 brainstem transected adult animals of both sexes was used in these electroencephalographic studies. They included 10 albino rabbits, 9 cats and 6 Macaca cynamologous and 3 Macaca mulatta monkeys. The animals were prepared under diethyl ether

*Supported in part by Grant B 1311 USPHS.

$\dagger$ A preliminary report was presented at the meeting of the Central EEG Society (KNAPP and DomINO, 1961). $\$$ Postdoctoral Fellow BF-10,253 USPHS. Present address: Department of Dental Therapeutics, The University of Michigan School of Dentistry, Ann Arbor, Michigan.

** Midpontine refers to an intercollicular, midpontine, pretrigeminal section.

\$Prepontine refers to an intercollicular, prepontine section. 
anesthesia or $2 \%$ lidocaine anesthesia following immobilization with decamethonium. When indicated, respiration was maintained artificially with positive pressure ventilation. The femoral artery was cannulated for recording blood pressure with a mercury manometer and a femoral or saphenous vein was cannulated for the intravenous administration of drugs. Electrical activity, from sensorimotor cortex of the rabbit and cat, and from motor cortex of the monkey, was recorded on a Grass electroencephalograph. Both monopolar and bipolar recordings were made with stainless steel electrodes. The elevated skin of the scalp was used as the indifferent site for monopolar recordings. Following the use of diethyl ether anesthesia, at least $3 \mathrm{hr}$ were allowed for elimination of this agent before the effects of various drugs were tested. At the conclusion of each experiment the animal was sacrificed. a postmortem EEG record taken, and calibration of the instrument repeated.

Brainstem transections in the rabbit, cat and monkey were performed with slight modifications of the technique described in detail previously for the dog (KNAPP and DOMINO, 1962). Essentially, this technique involves the use of intracranial bony landmarks for the determination of the level of transection followed by section of the brainstem with specially designed spatulas.

\section{RESULTS}

Rabbit. Intravenous doses of 4-8 $\mu \mathrm{g} / \mathrm{kg}$ of epinephrine were found to produce EEG activation when tested in 8 midpontine rabbits. Five rabbits responded at $4 \mu \mathrm{g} / \mathrm{kg}$ of epinephrine; 3 at $8 \mu \mathrm{g} / \mathrm{kg}$. In 2 of the rabbits, injected with $8 \mu \mathrm{g} / \mathrm{kg}$ of epinephrine. EEG activity deteriorated during the pressor response. Postmortem evidence of extensive intracranial hemorrhage was found in both of these animals. In the 6 remaining rabbits, the mean duration $\pm \mathrm{SD}$ of the epinephrine induced EEG activation responses was $1.02-0.58$ min. Although 5-hydroxytryptamine did not produce EEG activation in the midpontine dog, this agent did produce EEG activation responses when tested in the midpontine rabbits which survived injection of epinephrine. The intravenous injection of $30 \mu \mathrm{g} / \mathrm{kg}$ of 5 -hydroxytryptamine in these 6 midpontine rabbits produced EEG activation responses the mean duration \pm SD of which was $1.35 \pm 0.68 \mathrm{~min}$. Nicotine, too, was tested in these midpontine rabbits. An intravenous dose of $10 \mu \mathrm{g} / \mathrm{kg}$ of nicotine produced an EEG activation response in each of the 6 animals. The mean duration + SD of the nicotine induced EEG activation responses was $2.47 \pm 0.56 \mathrm{~min}$. In view of the failure of nicotine to produce $E E G$ activation in prepontine transected dogs (KNAPP and DOMINo, 1962), 2 prepontine rabbits were tested with nicotine. An intravenous dose of $10 \mu \mathrm{g} / \mathrm{kg}$ produced an EEG activation response in 1 of the 2 prepontine rabbits. The animal not responding at $10 \mu \mathrm{g} / \mathrm{kg}$ did respond following an intravenous dose of $20 \mu \mathrm{g} / \mathrm{kg}$ of nicotine. Interestingly, the intravenous administration of $8 \mu \mathrm{g} / \mathrm{kg}$ of epinephrine did not produce EEG activation in either of these prepontine transected rabbits in spite of producing increases in blood pressure from $68-102 \mathrm{~mm} \mathrm{Hg}$ larger than those observed following the activation dose of nicotine. Floris et al. (1962) also have reported EEG activation in mesencephalic transected rabbits following intravenous doses of nicotine.

Cat. In confirmation of Bonvallet et al. (1954), an intravenous dose of $4 \mu \mathrm{g} \mathrm{kg}$ of epinephrine produced EEG responses in all 6 midpontine cats tested. The mean duration $\pm \mathrm{SD}$ of the epinephrine induced EEG activation responses was $1.30 \pm 0.59 \mathrm{~min}$. Similar to the observations of GLASSER and MANTEGAZZINI (1960) 5-hydroxytryptamine also produced EEG activation in these midpontine cats. The intravenous administration of $30 \mu \mathrm{g} / \mathrm{kg}$ of 5-hydroxytryptamine produced EEG activation responses the mean duration $\perp_{-} \mathrm{SD}$ of 
which was $2 \cdot 36 \pm 1 \cdot 24 \mathrm{~min}$. In further confirmation of BoNVALLET et al. (1954), intravenous injection of $8 \mu \mathrm{g} / \mathrm{kg}$ of epinephrine did not produce EEG activation in 3 cats transected at a prepontine level. As in the case of the rabbit, however, nicotine produced an EEG activation response in both midpontine and prepontine transected cats. Four midpontine cats which had not deteriorated after injections of epinephrine and 5-hydroxytryptamine and 2 prepontine cats which survived the $8 \mu \mathrm{g} / \mathrm{kg}$ dose of epinephrine, were tested with nicotine. Three of the 4 midpontine and the 2 prepontine cats responded at $10 \mu \mathrm{g} / \mathrm{kg}$ of nicotine. The other midpontine animals, not responding at $10 \mu \mathrm{g} / \mathrm{kg}$, did respond at $20 \mu \mathrm{g} / \mathrm{kg}$ of nicotine. The mean duration $\perp$ SD of the nicotine induced EEG activation responses in the cat was 3.60 土 $1.07 \mathrm{~min}$.

Monkey. Intercollicular, midpontine, pretrigeminal brainstem transection produced a stable, spindling slow wave EEG in rabbits, cats, and as reported previously (KNAPP and Domino, 1962) in dogs. Surprisingly, a similar level of brainstem transection in 9 monkeys produced little if any alteration in the low voltage, fast frequency EEG. In an attempt to induce a slow wave EEG, these animals were then sectioned at a slightly more rostral level, approximately $2-3 \mathrm{~mm}$ caudal to the anterior border of the pons. Figure 1 illustrates the relatively high level of brainstem transection found necessary to induce a slow wave EEG in the monkey. In the 6 monkeys which survived the more rostral transection, a marked alteration of EEG activity was observed. The alteration consisted chiefly of the appearance of 5-9 cs waves of approximately $200 \mu \mathrm{V}$ amplitude. The high voltage, slow waves were occasionally grouped into poorly formed spindle-like bursts. Epinephrine, 5-hydroxytryptamine, and nicotine were tested in these monkeys. The intravenous injection of $8 \mu \mathrm{g} / \mathrm{kg}$ of epinephrine, as in the case of the midpontine dog, did not produce EEG activation in the pontine transected monkey. 5-Hydroxytryptamine $(30 \mu \mathrm{g} / \mathrm{kg}$ i.v.) also proved ineffective in producing EEG activation in the monkey. As in the case of the rabbit, cat, and dog, nicotine did produce EEG activation in the monkey. Three monkeys responded at an intravenous dose of 10 $\mu \mathrm{g} / \mathrm{kg} ; 3$ at $20 \mu \mathrm{g} / \mathrm{kg}$. In the monkey the mean duration of the nicotine induced EEG activation responses $\pm \mathrm{SE}$ was $4.83 \pm 2.30 \mathrm{~min}$. Interestingly, in all cases the pressor response to the EEG activation dose of nicotine was less than that observed with the injections of epinephrine or 5-hydroxytryptamine.

Species Comparisons. The species differences in the EEG response to epinephrine, 5-hydroxytryptamine, and nicotine are shown in Figs. 2, 3, and 4. Fig 2 illustrates epinephrine induced EEG activation in the rabbit and cat. As can be seen, however, the dog and monkey displayed no such alteration in EEG activity following epinephrine. The effect of 5-hydroxytryptamine, illustrated in Fig. 3, similarly shows the absence of 5-hydroxytryptamine induced EEG activation in the dog and monkey, although both the rabbit and cat did respond. Fig. 4 illustrates nicotine induced EEG activation in all four species. As can be seen in the left hand panels, EEG spindles are a prominent feature in the pre-injection control records of the rabbit, cat and dog. The monkey displays a somewhat different high voltage, slow wave background, with poorly formed spindle bursts. The panels to the right 1 min post injection, illustrate the shift to higher frequency, lower amplitude EEG waves, following the intravenous injection of $10-20 \mu \mathrm{g} / \mathrm{kg}$ of nicotine.

\section{DISCUSSION}

Both intravenous epinephrine and 5-hydroxytryptamine produced EEG activation responses in midpontine rabbits and cats, but not in midpontine dogs or high pontine monkeys. These observations may suggest species difference in brain permeability or differences in the 
spatial distribution of the receptors or portions of the essential neuronal circuitry involved in epinephrine and 5-hydroxytryptamine induced EEG activation. These findings do not necessarily indicate that intravenous epinephrine or 5-hydroxytryptamine cannot produce EEG activation in intact or more caudally transected dogs and monkeys. In fact, as shown in unpublished studies by one of us, high spinal vagotomized dogs show EEG activation to even small doses ( $1 \mu \mathrm{g} / \mathrm{kg}$, intravenously) of epinephrine. Of course, it is common knowledge that such high spinal preparations may display EEG activation following a wide variety of pharmacologic and physiologic maneuvers.

Further species differences were observed with nicotine. This agent did not produce EEG activation in prepontine dogs (KNAPP and DoMINO, 1962) but did produce EEG activation in prepontine rabbits and cats. Epinephrine, however, was ineffective in producing EEG activation in prepontine rabbits and cats. It appears, at least in brainstem transected animals, that not only level of transection, but species differences too, are important variables in the EEG activation response to drugs.

RosSI and ZIRONDOLI (1955) and Roger et al. (1956) reported trigeminal input was a dominant factor in the maintenance of a low voltage, fast frequency EEG in the high spinal cat. BATINI et al. (1958), however, using a cerebellar approach, performed an angled pretrigeminal section of the cat brainstem, and found that low voltage, fast frequency cortical waves persisted. Slightly more rostral sections through the pons were found to produce EEG spindles. In the current study intercollicular, midpontine pretrigeminal transection produce spindling EEG's in the rabbit, cat, and dog, but not in the monkey. This observation in the monkey lends further to the argument of BATINI et al. (1958) that trigeminal input is not necessarily involved in the maintenance of EEG "persistent patterns of wakefulness". That slightly more rostral pontine sections synchronized the monkey EEG is also consistent with the observations of BATINI et al. (1958) in the cat. As concluded by these investigators, the injury or the integrity of a small amount of nervous tissue in the pons is a critical factor in determing whether or not the EEG is synchronized.

It is hoped that these findings will reaffirm the need for caution in transferring the results of neuropharmacological experimentation from one species to another.

Résumé-Lors de l'activation EEG induite par l'adrénaline, la 5-hydroxytryptamine (5HT) et la nicotine, des différences d'espèces ont été observées entre le lapin, le chat, le chien et le singe.

Pour l'induction d'un tracé EEG d'ondes lentes chez le chien, la transsection du tronc cérébral doit être relativement haute.

L'activation EEG a pu être induite par $10-20 \mu \mathrm{g} / \mathrm{kg}$ de nicotine chez le lapin, le chat et le chein à section médio-pontique (intercolliculaire, prétrigéminale) ainsi que chez le singe à section pontique supérieure.

Des doses similaires de nicotine entraînent également une activation EEG chez le lapin et le chat à section prépontique (intercolliculaire, prépontique), mais pas chez le chien prépontique.

De même, alors que 4-8 $\mu \mathrm{g} / \mathrm{kg}$ d'adrénaline et $30 \mu \mathrm{g} / \mathrm{kg}$ de $5 \mathrm{HT}$ induisent une activation EEG chez le lapin et le chat médio-pontiques, une telle résponse n'a pu être observée après administration de ces substances chez le chien médio-pontique et le singe à transsection pontique haute.

\section{REFERENCES}

Batini, C., Moruzzi, G., Palestrini, M., Rossi, G. F. and Zanchetti, A. (1958). Persistent patterns of wakefulness in the pretrigeminal midpontine preparation. Science 128: 30-32. 
Bonvallet, M., Dell, P. and Hrebel, G. (1954). Tonus sympathique et activité électrique corticale. E.E.G. Clin. Neurophysiol. 6: 199-144.

Floris, V., Morocutri, G. and Ayala, G. F. (1962). Axione della nicotina sulla attivata bioelettrica della corteccia del talamo e dell ippocampo nel coniglio. Sua azione di "arousal" e convulsivante primitiva sulle strutture ippocampo-talamiche. Boll. Soc. Ital. Biol. sper. 38: 407-410.

Grbas, F. A. and MaltBy, G. L. (1943). Effect of the electrical activity of the cortex of certain depressant and stimulant drugs - barbiturates, morphine, caffeine, benzedrine and adrenaline. J. Pharmacol. 78: $1-10$.

Glasser, A. and MANTEGazzinI, P. (1960). Action of 5-hydroxytryptamine and of 5-hydroxytryptophan on the cortical electrical activity of the midpontine pretrigeminal preparation of the cat with and without mesencephalic hemi-section. Arch. Ital. Biol. 98: 351-366.

KNAPP, D. E. and Domino, E. F. (1961). Species differences in the effect of intravenous epinephrine and serotonin on the EEG. E.E.G. clin. Neurophysiol. 13: 144.

KNAPP, D. E. and Domino, E. F. (1962). Action of nicotine on the ascending reticular activating system. Int. J. Neuropharmacol. 1: 333-351.

LoNGo, V. G. (1962). Electroencephalographic atlas for pharmacological research. Rabbit Brain Research. Vol. 2. Elsevier, Amsterdam, p. 45-52.

Roger, A., Rossi, G. F. and Zirondoli, A. (1956). Le rôle des afférences des nerfs crâniens dans le maintien de l'état vigile de la préparation "encéphale isolé". E.E.G. Clin. Neurophysiol. 8: 1-13.

Rossı, G. F. and ZIRoNDoLI, A. (1955). On the mechanism of the cortical desynchronization elicited by volatile anesthetics. E.E.G. Clin. Neurophysiol. 7: 383-390. 